$12-9-2010$

\title{
Bam! Pow! Graphic Novels Fight Stereotypes in Academic Libraries: Supporting, Collecting, Promoting
}

Beth Jane Toren

West Virginia University, beth.toren@mail.wvu.edu

Follow this and additional works at: https://researchrepository.wvu.edu/lib_faculty

Part of the Collection Development and Management Commons, Film and Media Studies Commons, and the Higher Education Commons

\section{Custom Citation}

Toren, Beth Jane. "Bam! Pow! Graphic Novels Fight Stereotypes in Academic Libraries: Supporting, Collecting, Promoting." Technical Services Quarterly 28, no. 1 (2010): 55-69. doi:10.1080/07317131.2011.524523.

This Article is brought to you for free and open access by the University Libraries at The Research Repository @ WVU. It has been accepted for inclusion in University Libraries Faculty Scholarship by an authorized administrator of The Research Repository @ WVU. For more information,

please contact ian.harmon@mail.wvu.edu. 


\title{
Bam! Pow! Graphic Novels Fight Stereotypes in Academic Libraries: Supporting, Collecting, Promoting
}

\author{
BETH JANE TOREN \\ West Virginia University Downtown Campus Library, West Virginia University, \\ Morgantown, $W V$
}

This study examines the launch of a graphic novel collection in an academic library and presents a study analyzing the increase of titles in American Research Libraries with the subject heading "Graphic Novels" between fall 2008 and fall 2009. Statistics show a 40\% increase, averaging 62 additional titles, during a year of global financial crisis. Exploring the prejudice against comics lingering in more traditional corners of academia, this paper encourages librarians to counter stereotypes and therefore bring more people, including other librarians, to view graphic novels as literature. This study includes recommended practices for supporting, collecting, and promoting these collections.

KEYWORDS graphic novels, academic libraries, comics, super- heroes, stereotypes, collection development, displays, sequential art, visual narratives, Association of Research Libraries

Graphic novels (GNs) are moving from being marginalized to being on the cutting edge of collection development in academic libraries. West Virginia University (WVU) is a public research university with an enrollment of about 28,000 and a faculty of about 1,870 . The WVU libraries began collecting GNs to support our reference department's Film and Media Literacy course, which includes a module on film adaptations of GNs. We wanted to determine if other WVU instructors were using GNs in the classroom, indicating an expansion to our collection would be in order, and if academic libraries were developing GN collections. A request was placed through the university's employee electronic newsletter for instructors to respond if they used GNs in their classes, and to include the GNs they used. This informal survey included enthusiastic responses from the faculty from the English, Women's Studies, and Education departments and identified more than 20 courses that used GNs as texts. Inspired by these results, our small collection was promoted using suggestions from O'English, Matthews, and Lindsay'sarticle recommending that outreach is required to help overcome stereotypes that many academics associate with "comics" (2006). Student assistants were then trained to search Association of Research Libraries (ARL) library catalogs to collect statistics on their collections. Issues surrounding GN in public libraries were researched to find best practices that could be transferred to academic libraries. 
Interest and feedback from the audience during WVU Libraries' GN presentations at library conferences was enthusiastic, and bi-monthly statistics (1) showed dramatic increases in the collections of GNs in ARL libraries. Their potential for collection development in academic libraries is growing. A study by Wagner takes a different approach to researching GNs in ARL libraries and complements the recommendations in this study (Wagner, 2010). While this study examines holdings in ARL Library catalogs gathered by conducting subject-heading searches to further study the trend documented by O'English, Wagner searched for specific titles from acknowledged out- standing choices for academic libraries to analyze. Wagner's analysis of GNs in academic ARL libraries found them wanting. Wagner concludes that although the majority of academic ARL libraries do not "aggressively collect graphic novels ... to better serve scholarly research in this area of increasing interest, libraries will need to reexamine their collecting policies" (Wagner, 2010, p. 1). Academic librarians face challenges supporting, collecting, and promoting GN collections, some of it due to longstanding societal and academic prejudices against comics. GNs are developing an established and respected place in academia that has caught the interest of an increasingly large audience. It is the place of academic librarians to champion their cultural, literary, and intellectual value in order to invite more people into that growing audience that respects rather than stereotypes the GN.

O'English's article “Graphic Novels in Academic Libraries: From Maus to Manga and Beyond" provides a detailed history of the GN and cites many examples to establish their legitimacy as literature (O'English, Matthews, \& Lindsay, 2006). She notes that the subject of GNs is being covered in respected news sources. Comics were deemed "sequential art" by Will Eisner, a pioneer in the genre (McCloud, 1994). Visual literacy, one of multiple literacies grouped with information literacy by the Association of College and Research Libraries (ACRL), is required to fully appreciate this art (ACRL, 2009). O'English calls the GN "a sophisticated partner to film and other electronic media" (O'English et al., 2006). The article provides excellent support if one is making a case for GN in their library or facing faculty and staff that are stereotyping GNs as "funnies" or entertainment for the sub-literate.

GNs are merely long comic books to the uninitiated, and comics them- selves have a long history of prejudice in American culture. In the 1950s, there was a great scare, including congressional hearings, firmly establishing the corrupting influence of comic books on children. William Gaines, publisher of many horror and crime comics, and also Mad Magazine, testified (Hajdu, 2008). Afterwards, Gaines stopped publishing all his comics in the popular Entertaining Comics (EC) line except Mad, which was a magazine rather than a comic, thus protecting it from the new, strict Comics Code. Wagner points to white-male 
domination of the industry, yet offers much hope for the increasing numbers of female and ethnic authors and writers (Wagner, 2010). A sad example is the first black character in Marvel Comics. He was named Whitewash Jones and served a stereotyped and "minstrel show inspired" role (University of Illinois at Urbana-Champaign, 2007). Efforts to overcome this prejudice have been to collect information about GN collections in ARL libraries in order to document their growth and to gather, share, and carry out best practices for supporting, collecting, and promoting a GN collection in an academic library in a non-prejudicial manner.

\section{METHOD}

GNs were being used in the Film and Media Literacy course at WVU, and the English literature bibliographer was ordering GNs that had been adapted into films for the students in that course. WVU strives to be "student-centered," adding additional graphic novels to our collection would be one way to serve the interests of some underserved parts of the student population, the majority of whom were visual learners and many who were interested in reading GNs. Wagner notes that "contemporary culture ... is ... increasingly visually oriented" (Wagner, 2010, p. 11). Today's students are the perfect tar- get audience. An informal investigation into whether a GN collection would support the university curriculum as well as the leisure reading collection was initiated. An informal survey of our faculty at WVU was conducted. In April 2008, this announcement was released in the weekly newsletter delivered to all faculty email accounts:

RESEARCH: 14) WVU researcher seeks information on use of graphic novels in the classroom

Faculty members: Have you ever used a graphic novel in the classroom? Do you know of anyone else who did? The Web services and reference librarian, would like to hear from you.

Contact information followed. In addition, advice from librarian advocates of GNs was gathered, and a visit to the city's public library to learn how they managed their collection was made. During a statewide presentation targeted at both academic and public librarians, school librarians who attended offered additional support and information. 
Library and education literature indicates the visual narrative is as valid a form of literature as the textual narrative, and that the quality of the GN was increasing. To document the trend described in O'English (2006) and McCloud (1994), the second step to investigate the questions "how big are GN collections in ARL libraries, and how fast are they growing?" was taken. Quantitative data was gathered as evidence in the case to defend the GN from critics. This was particularly because many people, including library faculty and staff, might see the GN as a comic book, and comics have suffered through terrible times of being censored and having their reputation besmirched. Student assistants helped to systematically search the ARL library catalogs listed at the ARL membership page for the number of titles cataloged with the Library of Congress subject heading "Graphic Novels." The number of titles counted was limited to titles found under that subject heading, and no titles with only that Library of Congress Subject Heading (LCSH), including a subheading or variation, were counted. Searches were conducted in the first week of September 2008, again in February 2009, and again in the first week of September 2009. The number of titles in each search was averaged, and the increase and percent of increase was noted (Figure 1, Table 1). This search would not find every single GN because some catalogers call what some consider a GN "comic books, strips, etc.," for example, when the story was originally published in a four-issue comic and then compiled in a GN release. Cataloging could be inconsistent across libraries (O'English et al., 2006). This search would also find books about GNs, indicating the growing trend in GN scholarship. In addition, the results compiled were for all the ARL libraries, some of which are not affiliated with research universities. Wagner cut out the French catalogs and other libraries not affiliated with an academic institution (Wagner, 2010). Some of the libraries included in the WVU study, like the Library of Congress, collect nearly everything published, while others are very scientifically oriented and collect zero titles.

\section{RESULTS}

Responses to the campus news survey included how a course in Women's Studies used Wonder Woman to study the role of female superheroes over time. One English instructor had students writing papers on the GN Persepolis, and Lois Lane and feminism. Another from the English Department declared "If the library is considering acquiring additional graphic novels, then count me among the enthusiastic supporters!" In all, the survey identified over 25 courses that used graphic novels as texts. This encouraged the analysis of the collections in ARL libraries. 
One common denominator that impacted nearly every library budget some time during 2009 was the global financial crisis that began in September 2008. Despite this, the acquisition of titles in ARL libraries remained steady throughout the year. The first comparison was performed at a five month- interval, and then the same analysis was conducted exactly one year after the original search. The results of the quantitative analysis of books with the LCSH Graphic Novels in ARL catalogs are as follows:

\begin{tabular}{|l|r|r|r|}
\hline Date searched & 1-Sep-08 & 1-Feb-09 & Increase \\
\hline & & & 27 \\
\hline Average number of titles in ARL Libraries & 154 & 181 & 3269 \\
\hline Total number of titles in ARL Libraries & 18716 & 21923 & $17 \%$ \\
\hline Percent of increase & & & \\
\hline
\end{tabular}

\begin{tabular}{|l|r|r|r|}
\hline Date searched & 1-Sep-08 & 1-Sep-09 & Increase \\
\hline & & & 62 \\
\hline Average number of titles in ARL Libraries & 154 & 216 & 7607 \\
\hline Total number of titles in ARL Libraries & 18716 & 26323 & $40 \%$ \\
\hline Percent of increase & & & \\
\hline
\end{tabular}

FIGURE 1. Titles under the LCSH "Graphic Novels" in ARL Libraries.

TABLE 1 Average Number of Titles in ARL Libraries with LCSH Graphic Novels

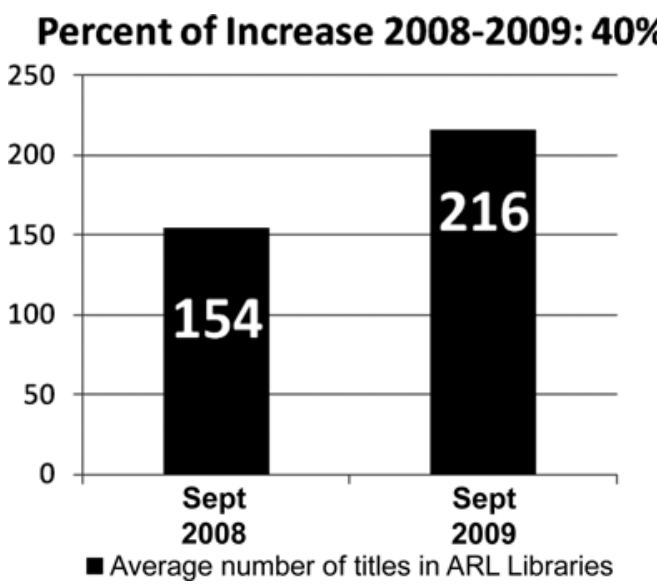

Despite the onset of a global financial crisis, ARL libraries increased their number of titles with the subject heading "graphic novels" by $40 \%$ the following year. On average, they acquired 62 titles. 


\section{RECOMMENDATIONS}

Observing the growth of collections in ARL libraries during one year shows that they are collecting the titles and there is scholarly activity in this area, but more remains to be done with continued observation of the collections over time. Also, other subheadings could be studied, such as "Graphic Novels- Japan" and in other subject areas like "Comic books, strips, etc.-Japan- Translations into English." Other subheadings in these areas can include African Americans, adolescent girls, and other ethnic and minority groups that would make good areas of study.

Surveying the target audience to ask them about their reading habits and preferences in GN themes and authors will provide helpful criteria for title selection. There is a twofold role the GN plays for the readers, just as literature without visual art. Its role is both literary and educational; it serves as entertainment and recreation. This audience survey may be an opportunity to find out what other types of recreational materials the students are interested in that the library might provide. Perhaps they are interestedin broadening the collection to include things like Japanese manga (comics) in translation, or other international titles; perhaps they are interested in Anime, animated Japanese films that are often adaptations of manga. There might even be a Japanese club on campus that one could do a focus group or survey with to identify titles they are interested in and then compare those to reviews and awards lists.

\section{SUPPORTING GN COLLECTIONS}

For many people, the idea of a book with pictures lends itself to the image of a children's book like Eric Carle's The Very Hungry Caterpillar. This is their primary association because they have not encountered the modern GN. Then they might think of a special children's collection. Thus their first impression of GNs in an academic library is like oil and water. Other objections that might then come to mind are that GNs could undermine literacy, subtract from the academic atmosphere of a research library, and infantilize the students. Some may fear that superhero titles promote antiquated stereotypes such as Superman rescuing a helpless Lois Lane. Given all this, they see no place for GNs in the college or university library.

Who might have negative thinking when it comes to developing a GN collection in an academic library? Administrators, faculty, librarians, staff, students, and parents might all have a variety of objections. How 
do we support the change in paradigm required to embrace or at least tolerate this somewhat new to academia medium? When supporting the collection to members of the academic community, use techniques to educate them about the legitimacy of GNs as literature. For example, know the traits that separate GNs from comics. GNs are frequently visual novels of book length; they have complex storylines for mature audiences. They are durable and sold at bookstores, and often have a higher standard of art than a typical comic; stories are usually complete in one novel, and as in an average textual narrative book, they are serious, mature, and literary. The modern graphic novel is written for mature adults and can compete with adult literature. GNs have won Pulitzer prizes and Hugo awards previously reserved for exclusively textual narrative literature. Much more than superhero books, they treat all manner of adult subjects including war, alcoholism, racism, relationships, and every literary genre.

Be ready to give examples about how GNs or comics are used in the higher education classroom. Explain that the format engages all the students, that the majority of the students are visual learners, and that GNs exercise the visual learning skills of those who are not primarily visual. In a study of college freshman published in 2007, "approximately $64 \%$ of the subjects displayed a desire for visual text learning" (Cutolo \& Rochford, 2007, par. 18). Learners use complex cognitive functions when both reading text and following a visual narrative. A recommended way to learn about this in more detail is to read the nonfiction GN Understanding Comics by Scott McCloud (McCloud, 1994).

A visual narrative can be as moving as a written narrative. One may read a bland page of narrative that brings nothing memorable to mind and forget the substance the moment the page is turned. In contrast, one may contemplate one page, sometimes one panel of a visual narrative, an illustration with few or no words repeatedly while the story burns permanently into memory and personal associations turn over and over, settling into an understanding of the work, its characters, their lives, their tragedy, and the human condition. A moving example for some librarians is from a superhero title, DC's Batman: The Killing Joke. In the following one page visual narrative, the Joker shoots and cripples Barbara Gordon while her father, Commissioner Gordon, watches. She is no longer Batgirl; ever since then she has used a wheelchair, and her character is transformed (Moore, Bolland, \& Starkings, 2008). ${ }^{2}$ 


\section{COLLECTING}

Funding a collection may be the first obstacle if a collection does not exist. Consider talking with bibliographers and acquisitions representatives who control the funds in the areas of English literature, science fiction, leisure reading, or specific funds for titles that match the bibliographer's subject area. In each case, it will be helpful to bring a list of titles with prices and possibly reviews, along with the reassurance that these are for a mature audience. Search the local catalog, and one may be surprised that there are already a few in the collection. Do not forget that the cataloging is complicated and may be inconsistent, so browsing several subject headings that include the words "comics or graphic novels" is a good idea (O'English et al., 2006). 

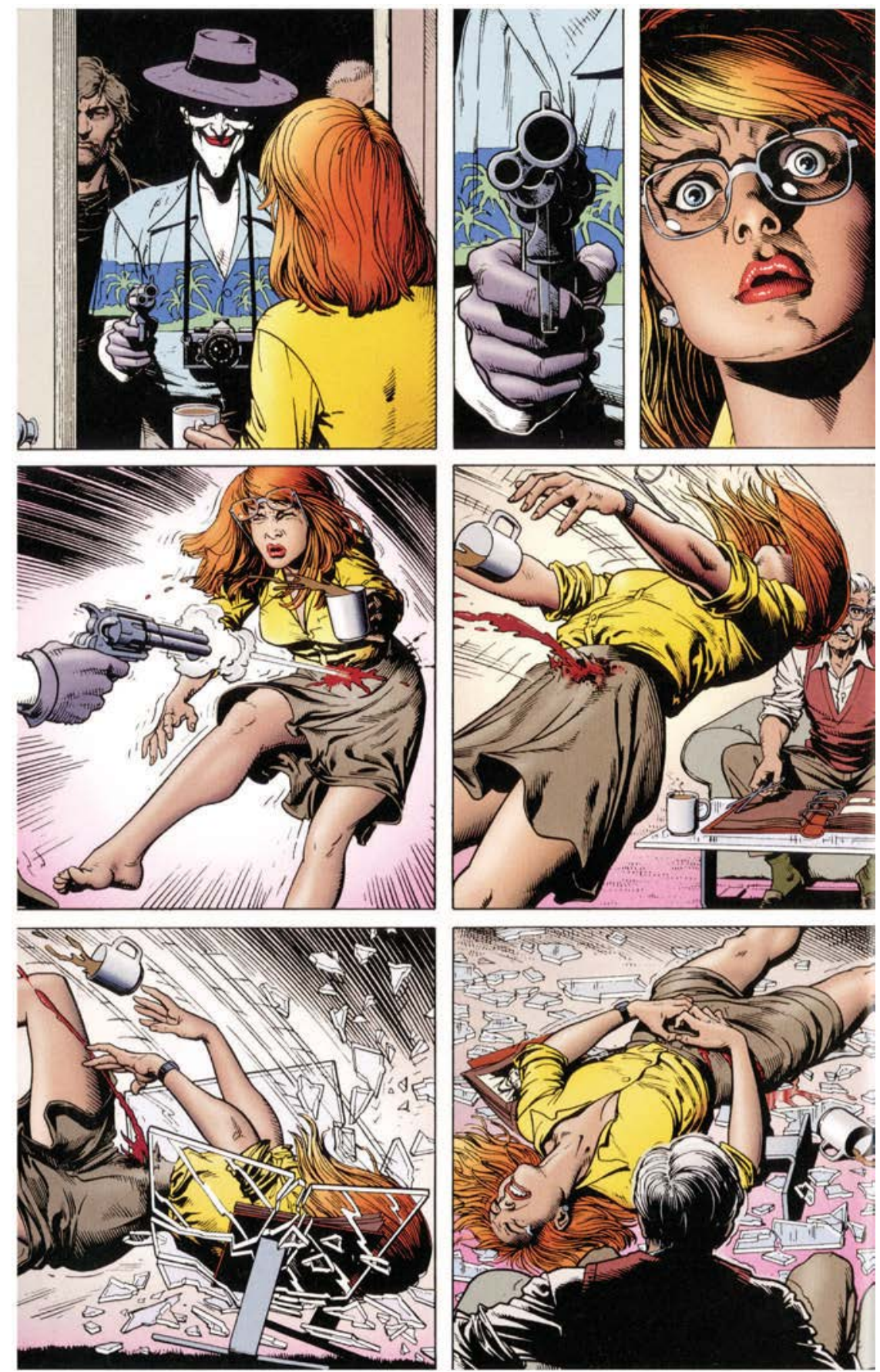

IMAGE 1. Batgirl, Barbara Gordon, paralyzed by the Joker. (Reprinted with permission.) 
Outside of a children's collection for a teaching program in an education department, in an academic library one should collect titles for adult readers. A good core collection can be started with award winners, which are easy to find with a Web search for "graphic novel award winners." Find out what fits into the curriculum and support it. A large number of English department faculty at WVU wrote in response to the survey to say they used Maus in their classes. We found that we only had one very ragged copy and ordered a couple of duplicates. A collection development policy is needed, be it written or unwritten. Columbia has an excellent example on the Web of a written GN collection-development policy on their Web site. This can be found under the collection-development policies by format or on the GN's subject guide page (Graphic novels). It is okay to have unwritten criteria, but a high standard of criteria should exist. Factors in these criteria could be inclusion and diversity.

Comics themselves have suffered enough prejudice, and now the industry that produces them is gradually becoming more diverse. Yet it may still take extra effort to find the titles inclusive of race and gender and written or drawn by diverse artists. It is vital to have guidelines when developing your collection. Some of the other things to include are to aim for a mature audience, to buy a series beginning with the first issue and continuing in sequence, and fostering diversity by avoiding collecting for a single gender, age, or ethnic group. One may also practice collecting award winners. If buying a series such as Stephen King's The Dark Tower, purchase all the issues. Make sure the library labels do not cover the issue numbers, and that the numbers are easy to read. Coordinate purchases with other librarians if the GNs have other media associated with them. For example, coordinate book, film, and soundtrack purchases. A good example of this is the multiple award winner The Dark Knight.

\section{PROMOTING}

There were far fewer objections to collecting GNs than anticipated at the WVU Libraries. It helped that research, presentations, displays, and learning in this area was taking place. There was an initial collection based on our university curriculum, and there was a growing reading collection in our very popular coffee shop. Now there was a collection, and it was time to promote it. Permission was obtained from the administration to do two displays about GNs in glass cases, one for students and one for faculty. 


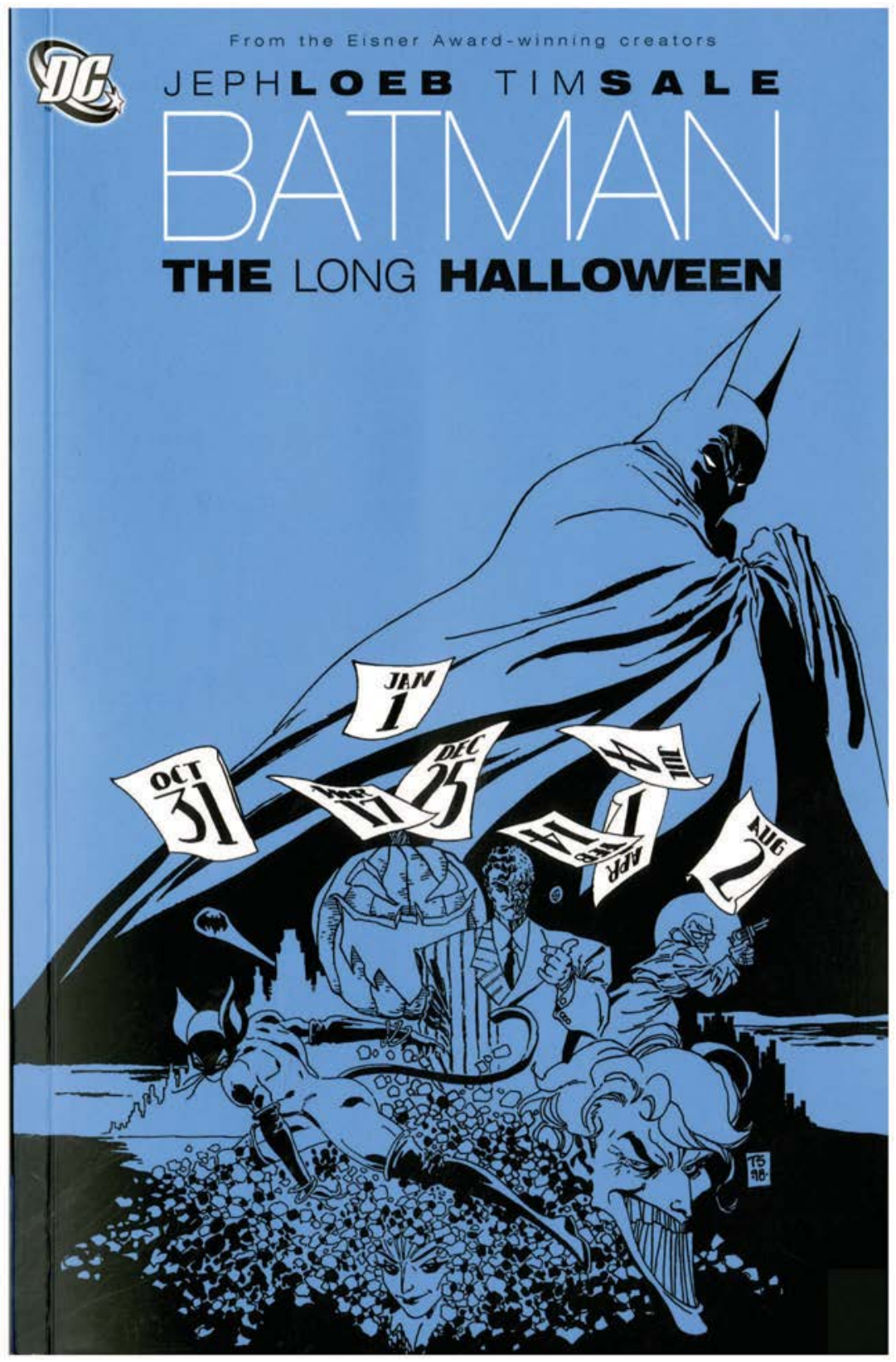

IMAGE 2. The award winning graphic novel Batman: The Long Halloween is one of the sources for the story in The Dark Knight (2008). (Reprinted with permission.) 

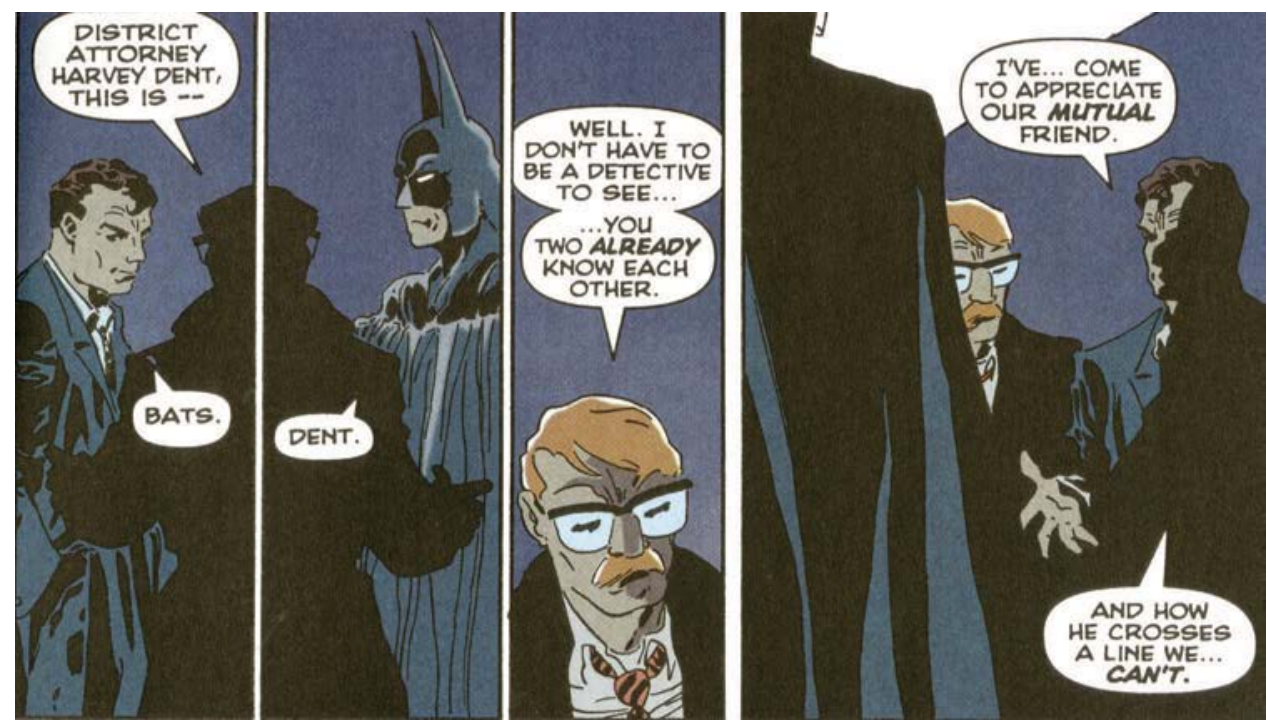

IMAGE 3. There were several other sources for the original screenplay The Dark Knight. This is a scene from Batman: The Long Halloween recreated in the film that illustrates a central theme of the story. (Reprinted with permission.)

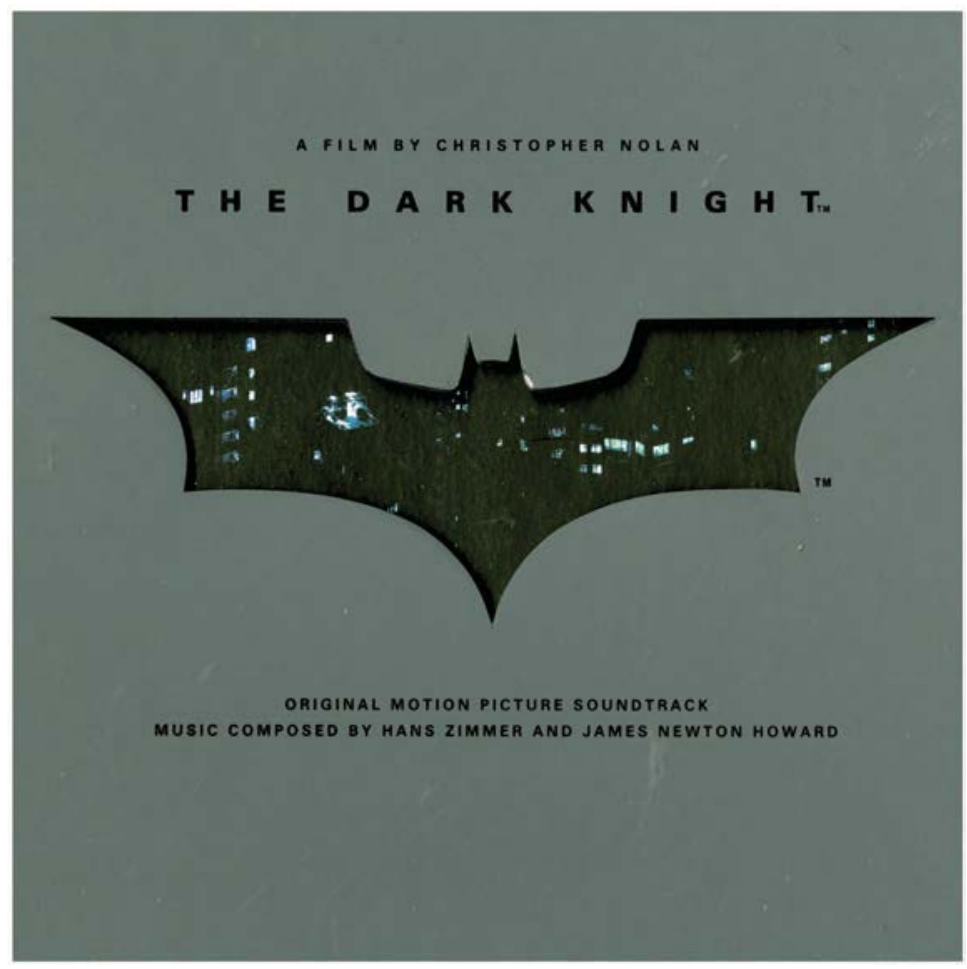

IMAGE 4. The The Dark Knight soundtrack won the Grammy for Best Score Soundtrack Albumfor Motion Picture, Television,orOtherVisual Media.(Reprinted with permission.) 


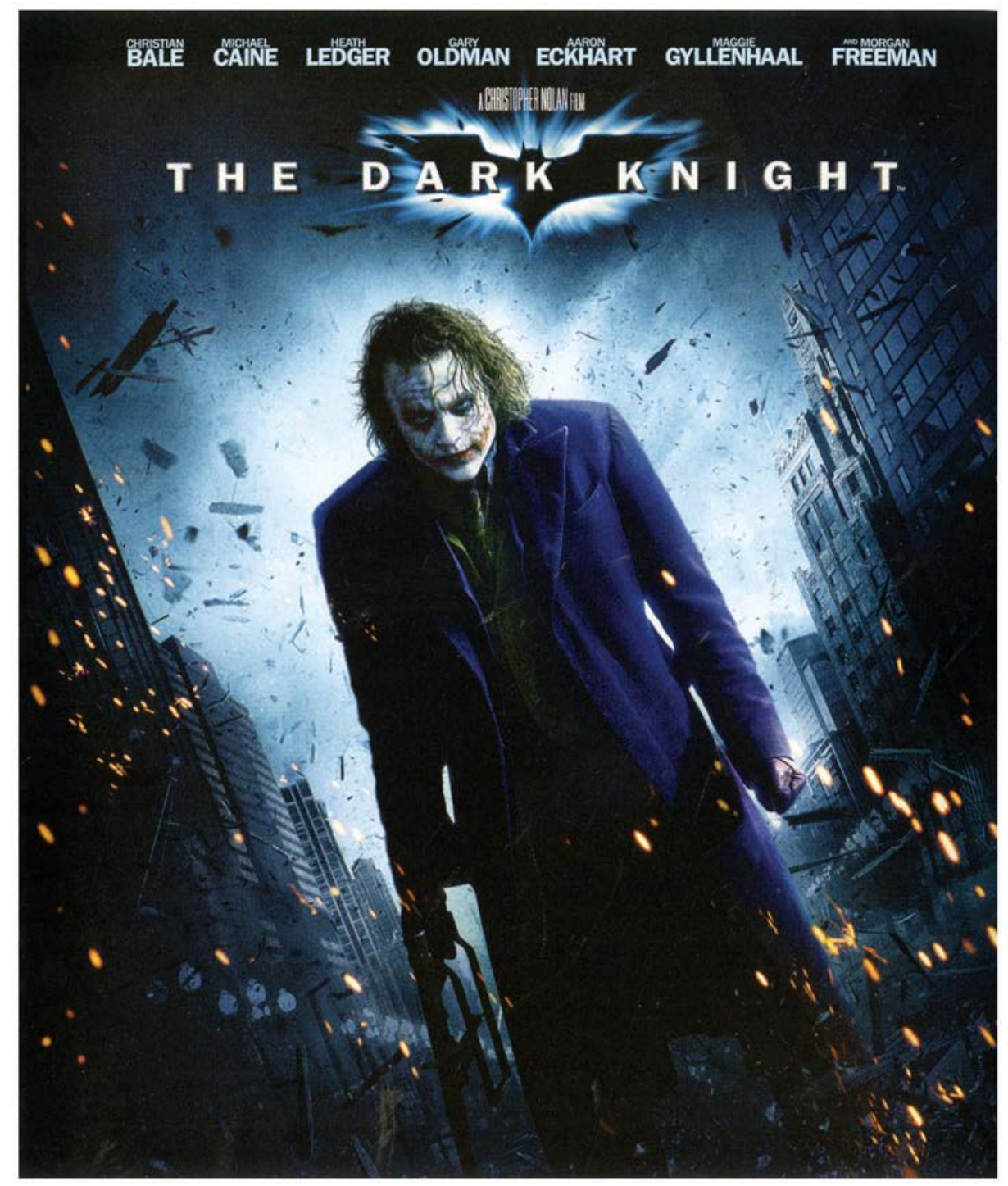

IMAGE 5. The movie adaptation The Dark Knight won Oscars (posthumously) for Actor in a Supporting Role and for Achievement in Sound Editing. It was nominated for six other Oscars. (Reprinted with permission.)

The one for faculty was called "Graphic Novels in the Classroom" and included books about teaching with GNs like Teaching visual literacy: Using comic books, graphic novels, anime, cartoons, and more to develop comprehension and thinking skills, and facts about the Pulitzer and Hugo award winners Maus and Watchmen. The one aimed at students was intended to attract them to the collection, to promote the library as a third place ${ }^{3}$ where we serve and respect all their reading interests and are up on the best, most popular and latest titles (Oldenburg, 1989). It featured titles from the season's popular film adaptations, like the 
sources for the Dark Knight and Wanted. It also gave directions for finding the collection. No actual books were used for that display; covers and color printouts were used so the books would be available for checkout.

Many methods exist to create buzz for a collection, and a scattered approach will reach the most people. First, there are library displays with themes limited only by the imagination. These should be colorful and informative and target a specific audience when they are created. Try to use color printouts, scans, and covers so the books remain available. Three-dimensional effects really make things pop, and this look can be achieved by using small pieces of dense Styrofoam between images printed and cut into shape on sturdy card stock paper. Next there are handouts. Brochures or pathfinders should include colorful and attractive graphics, recommended titles, locations and call numbers, and a descriptive paragraph. One may divide recommended titles into two categories: "Fantasy" and "History and Literature." Placement in a visible area is the best way to sell a product. Place GNs near the new books area, in the café, on a table in front of the large display, anywhere that can be dressed up and that users frequently pass. Place some of the books in book holders facing outward on the shelves so the covers are displayed. Rotate the ones on display frequently. Add the brochure in a dispenser with simple, colorful and easy-to-read signs. Create colorful fliers with a simple message and hang them in the dorms. A simple message might include instructions for finding or searching the collection.

Be sure to request that all the librarians giving orientation tours include the collection in their content. Once you have an established collection, consider speakers or workshops on the topic of GNs. At WVU there is a local, award-winning graphic novel artist who offered to speak, and he has conducted active learning workshops all over our state. Our GN section needs frequent straightening, and a pleasing and direct response from a user came in an exit interview from a student taking the film adaptations of graphic novels module in the film-andmedia literacy course:

Question 4: What did you like most about this course?

Student Response: Being exposed to some movies I would not have seen otherwise and opening my eyes to what I have been missing in some genres. For instance, I used to read a few comics when I was younger but not at all in the last 15 years or so until after starting this class. Since the start of this class I have read Watchmen, 300, V for Vendetta, Wanted, half of the Sin City books, half way 
through From Hell, the Complete Frank Miller Batman, and now have about 5 or 6 books on order through the EZBorrow program through the library that I am waiting to get. I am very into all the graphic novel stuff now and can't wait to get my hands on more.

\section{CONCLUSION}

A casual local survey indicated that there were many faculty using GNs in the classroom, and this kind of cost-free analysis can provide a useful snapshot when considering if GNs will support your curriculum. One year's data showed that ARL libraries are indeed building their GN collections even in times of financial crisis. Searches of the ARL library catalogs could be performed again in intervals to gather more comparative data. Immersing in the study of GNs will open up many avenues for championing a collection. Librarians need to spread the word, even amongst themselves, that they need to stay current with adult literature and literary trends and that GNs are an emerging area of scholarly study and a significant development in the contemporary adult literary marketplace. Academic libraries need to serve both the curricular and reading needs of the students, and a GN collection can do both. There are a variety of approaches to looking for funding, beginning selection, choosing selection guidelines, and promoting a collection. Like GNs, becoming an advocate for your collection can be both educational and fun.

\section{NOTES}

1. Not included in this paper.

2. Barbara Gordon's new secret identity is the cybrarian Oracle. She uses a wheelchair and fights crime by supplying superheroes with information she mines on the Internet.

3. Ray Oldenburg named home and work the first two places; the third place is vital to build a sense of place and community.

\section{REFERENCES}

ACRL. (2009). Information literacy for faculty and administrators. Retrieved October 1, 2009 from

http://www.ala.org/ala/mgrps/divs/acrl/issues/infolit/overiew/faculty/f aculty.cfm

Cutolo, Angela, and Regina A. Rochford. (2007). An analysis of freshmen learning styles and their relationship to academic achievement. College Quarterly, 10 (2), 1-17. Retrieved from ERIC October 5, 2009.

Graphic novels. Retrieved October 5, 2009 from 
http://www.columbia.edu/cu/lweb/eguides/graphic_novels/

Hajdu, David (2008). The ten-cent plague: The great comic-book scare and how it changed America (1st ed.). New York: Farrar, Straus and Giroux.

Loeb, Jeph, Tim Sale, and B. Kane. (1998). Batman: The long Halloween. New York, NY: DC Comics.

McCloud, Scott. (1994). Understanding comics: The invisible art (1st Harper Perennial ed.). New York: Harper Perennial.

Moore, Alan, B. Bolland, and R. Starkings. (2008). Batman: The killing joke (Deluxe ed.). New York: DC Comics.

O'English, Lorena, J. G. Matthews, and E. B. Lindsay. (2006). Graphic novels in academic libraries: From Maus to manga and beyond. Journal of Academic Librarianship, 32(2), 173-182. Retrieved October 5, 2009 from Library Literature \& Information Science.

Oldenburg, R. (1989). The great good place: Cafés, coffee shops, community centers, beauty parlors, general stores, bars, hangouts, and how they get you through the day (1st ed.). New York: Paragon House.

University of Illinois at Urbana-Champaign, Jackson State University, and Eye Trauma Studios. (2007). Other heroes: African American comic book creators, characters, and archetypes: art exhibition catalog. Retrieved October 5, 2009 from [S.l.]: lulu.com.

Wagner, Cassie. (2010). Graphic Novel Collections in Academic ARL Libraries. College \& Research Libraries, 71(1), 42-48.

Warner Home Video (Producer), and Christopher Nolan. (Director). (2008). The dark knight. [Video/DVD] Burbank, CA: Warner Brothers' Pictures. Zimmer, Hans, and J. N. Howard. (2008). The dark knight original motion picture soundtrack (Special ed.). Burbank, CA: Warner Sunset/Warner Bros. 